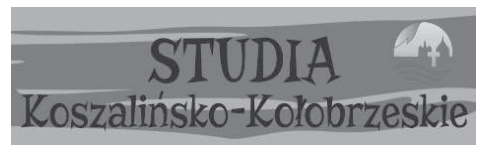

2017 nr 24

DOI: $10.18276 /$ skk.2017.24-10

Sławomir Zatwardnicki ${ }^{1}$

\title{
CHRYSTUS W NEXUS MYSTERIORUM
}

\begin{abstract}
Wstęp
Ponieważ w teologii wszystkie prawdy wiary zazębiają się ze sobą, „z tego powodu pisał Bernard Sesboüé - przypomina ona wielką pajęczynę, której najmniejsze poruszenie w jednym miejscu wywołuje falę drgań we wszystkich kierunkach”’2. Delikatną strukturę wzajemnie powiązanych ze sobą misteriów chrześcijańskich niektórzy teologowie próbują rozrywać za pomocą tzw. hierarchii prawd wiary. Paradoks polega na tym, że dopiero ten, który dał się złapać w „pajęczynę” jako całość, może dostrzec jej ustrukturyzowanie. I odwrotnie, całość nexus mysteriorum jest widziana właściwie jedynie $\mathrm{z}$ jej centrum. Również w tym owo zazębianie się daje o sobie znać: należy uwzględnić zarówno konieczność integrowania prawd wiary w całość (harmonia veritatum), jak i ich uporządkowanie (hierarchia veritatum).

Zagadnienie to zostanie rozwinięte w kolejnych paragrafach artykułu: najpierw autor przedstawi związek samoobjawienia się Boga $\mathrm{z}$ objawieniem prawd wiary, następnie zostanie ukazane, że tworzą one sieć wzajemnie powiązanych misteriów. W dalszej kolejności zostanie uzasadnione, że właściwie rozumiana „hierarchia” służy wszystkim tajemnicom wiary, a chrystologiczne centrum objawienia nie może prowadzić do marginalizowania pozostałych objawionych treści. W końcu autor wskaże na rolę ,zmysłu wiary" (sensus fidei) w uwzględnieniu zarówno całości, jak i poszczególnych misteriów wiary oraz ich relacji z Chrystusowym ośrodkiem.
\end{abstract}

\section{Objawiony Ktoś - objawienie czegoś}

Nie wolno sprowadzać objawienia do prawd wiary, które zostały przed człowiekiem odkryte. Jeśli Bóg opowiada lub milczy o tym, co kryje się w Jego sercu (coś więcej niż antropomorfizacja, wszak Bóg ma serce ludzkie) - dzieli się z człowiekiem sobą samym. Słowo Boże nazywa bogami tych, do których zostało ono skierowane (por. J 10,34-35).

1 Mgr Sławomir Zatwardnicki, doktorant na Papieskim Wydziale Teologicznym we Wrocławiu, autor wielu artykułów oraz dwunastu książek; ostatnio wydał: Gwałt na teologii (Warszawa, 2017). Z żoną i czwórką dzieci mieszka w Wałbrzychu. Adres do korespondencji: 58-300 Wałbrzych, ul. Moniuszki 33 m. 5; e-mail: zatwardnicki@gmail.com.

2 Bernard Sesboüé, Poza Kościołem nie ma zbawienia. Historia formuty i problemy interpretacyjne, thum. Agnieszka Kuryś (Poznań: W drodze, 2007), 14. 
Można by w słowach tych doszukiwać się górnolotnej przesadni, ale są one raczej sprowadzeniem Dobrej Nowiny do sedna. Objawienie nie oznacza czegoś, lecz przede wszystkim kogoś3. „Spodobało się Bogu w swej dobroci i mądrości objawić samego siebie i ukazać tajemnicę swej woli - cytuję Dei verbum, soborową konstytucję o Objawieniu Bożym - dzięki której ludzie przez Chrystusa, Słowo, które stało się ciałem, mają dostęp do Ojca w Duchu Świętym i stają się współuczestnikami Bożej natury"4. Objawienie jest zatem naszym, ludzi, zbawieniem; przy czym zbawieniem rozumianym po chrześcijańsku, a więc przebóstwieniem. Eschatologiczną humanizację człowieka utożsamić należy z darmowym przebóstwieniem, kiedy stworzenie będzie mogło uczestniczyć w komunii niestworzonych osób Trójcy Świętej. Zgodnie z soteriologicznym aksjomatem ojców Kościoła „Słowo Boże stało się człowiekiem, aby człowiek stał się Bogiem”.

„Wy już jesteście czyści dzięki słowu, które wypowiedziałem do was” (J 15,3) - mówi Słowo Wcielone do uczniów. Bóg wysławia się ,„po ludzku”, żeby człowiek mógł usłyszeć. Wtedy, gdy Bóg się wypowiada, a człowiek daje posłuch, wydarza się zbawienna komunikacja oraz dokonuje się przedziwna wymiana między tym, co boskie i co ludzkie. Osiąga ona swoje apogeum wraz z wydarzeniem wcielenia (które należy widzieć od poczęcia aż po wniebowstąpienie). Gdy Słowo Boże staje się człowiekiem, wtedy objawienie osiąga swoją pełnię, jest tożsame z samym Bogiem: „Wielokrotnie i na różne sposoby przemawiał niegdyś Bóg do ojców [naszych] przez proroków, a w tych ostatecznych dniach przemówił do nas przez Syna" (Hbr 1,1-2; por. Ga 4,4; Ef 1,10; Mk 1,15) Objawienie przychodzące z nieba to Bóg, Bóg dla ziemian, Bóg-człowiek, albo nawet

3 Tomasz Jelonek, Biblia w nauczaniu Kościoła (Kraków: Wydawnictwo WAM, 2011), 67: jeśli przed II Soborem Watykańskim objawienie miało ,raczej sens przedmiotowy, stanowiło pouczenie, które można ująć w pewien system”, to z kolei „nowe rozumienie objawienia kładzie nacisk na jego charakter podmiotowy i personalny” oraz podkreśla „dynamiczny proces objawienia, w którym Bóg przez słowa i czyny, wzajemnie ze sobą powiązane, przemawia do człowieka, a pełnia objawienia dokonuje się w osobie Jezusa Chrystusa".

4 Sobór Watykański II, „Konstytucja dogmatyczna o Objawieniu Bożym «Dei verbum»”, nr 13 (dalej DV), w: Sobór Watykański II, Konstytucje, dekrety, deklaracje. Tekst polski. Nowe tlumaczenie (Poznań: Pallottinum, 2002), 350 363 (dalej SWKDD).

5 Międzynarodowa Komisja Teologiczna, „Teologia, chrystologia, antropologia”, tłum. J. Bielecki, I, D, 1-2; I, E, 1, w: Od wiary do teologii. Dokumenty Międzynarodowej Komisji Teologicznej 1969-1996, red. Janusz Królikowski (Kraków: Wydawnictwo Księży Sercanów SCJ, 2000), 133-150 (dalej OWDT); Katechizm Kościoła katolickiego (Poznań: Pallottinum, 2002), 460 (dalej KKK); Atanazy z Aleksandrii, O wcieleniu Stowa, 54, 3, tłum. Michał Wojciechowski (Warszawa: Akademia Teologii Katolickiej, 1998), 73; Christoph Schönborn, Bóg zesłał Syna Swego. Chrystologia, współpr. Michael Konrad, Hubert Philipp Weber, tłum. Lucjan Balter (Poznań: Pallottinum, 2002), 105. Zdaniem Ratzingera antropologia wyzwolenia, jeśli ma osiągnąć swój cel, musi podjąć pytanie, jak jest możliwe bycie ,jak Bóg” czy stanie się Bogiem - Joseph Ratzinger, Patrzé na przebitego. Szkice o chrystologii duchowej, tłum. Jarosław Merecki (Kraków: Salwator, 2008), 30-31.

6 Międzynarodowa Komisja Teologiczna, „Interpretacja dogmatów (1988)”, tłum. Janusz Królikowski, ID B, I, 1, w: OWDT, 273-302. Objawienia nie wolno utożsamiać z Pismem Świętym, bo „Objawienie oznacza zbliżenie się Boga do człowieka i jest większe niż wyrazić mogą to ludzkie słowa, również większe niż słowa Pisma (...). Pismo jest znaczącym świadectwem o objawieniu, ale objawienie to coś żywego, coś większego (...) Joseph Ratzinger, Moje życie, oprac. wersji pol. Witold Wiśniowski (Częstochowa: Edycja Świętego Pawła, 2005), 106-107; Avery Robert Dulles, „From Ratzinger to Benedict”, First Things 160 (2006): 24-29, 26; Sławomir Zatwardnicki, „Relacja Objawienia do Pisma Świętego według Josepha Ratzingera (Benedykta XVI)”, Teologia $w$ Polsce 8, 1 (2014): 99-118. 
człowiek, a przecież Bóg7. Można powiedzieć, że objawienie to Bóg „dla nas ludzi i dla naszego zbawienia", czyli - raz jeszcze - przebóstwienia. Bracia Pierworodnego znajdą się tam, gdzie On już jest jako człowiek (por. Rz 8,29; Kol 1,15.18). Istnieje „współzależność pomiędzy humanizacją Boga a przebóstwieniem człowieka”, a „im głębiej Jezus Chrystus chciał stać się uczestnikiem ludzkiego ubóstwa - przywołuje Maksyma Wyznawcę Międzynarodowa Komisja Teologiczna - tym bardziej człowiek wznosi się w uczestniczeniu w życiu Bożym"9.

Dlatego ,wiara jest najpierw osobowym przylgnięciem człowieka do Boga”. Jednak, co ważne, ,równocześnie i w sposób nierozdzielny jest ona dobrowolnym uznaniem całej prawdy, którą Bóg objawił”10. „Najpierw” i „równocześnie” nie kłócą się, podobnie jak przylgnięcie do Kogoś oraz do czegoś pozostają w harmonii. Gdy Bóg dokonuje autoprezentacji, przedstawia zarazem również prawdę o sobie samym. Nie ma jednego bez drugiego; nie ma Jednego bez prawdy wiary o Trójcy. Zgodnie z Księgą Objawienia eschatologiczną lampą jest sam Bóg (por. Ap 22,5). Z kolei Trójlampa oświetla całą rzeczywistość, stąd Bóg, objawiając się - objawia treści obejmujące wszystko, w tym prawdę o człowieku, a jest to zawsze prawda z woli Bożej objawiona dla naszego zbawienia $^{11}$. Jak nie ma Boga objawienia bez objawionej treści, tak nie może być również chrześcijanina, który wierzyłby Komuś, lecz już nie czemuś. Konsekwentnie: nieprzyjęcie prawd objawionych - jest odrzuceniem Boga.

\section{Boska nexus mysteriorum}

Bóg jest zawsze pierwszy - oto Dobra Nowina chrześcijańska. Ludzie wszystkich czasów żebrali o przebaczenie grzechów, a to Ojciec pojednuje ze sobą przez swojego Syna (J 3,16; 2 Kor 5,19). Chrześcijanin, jeśli miłuje Boga, to tylko w odpowiedzi na Jego miłość, dzięki Duchowi Świętemu mieszkającemu w sercu ludzkim (Rz 5,5). Zdarza się, że wierzący oczekują, żeby ten Syn zamieszkał w nich, a to On, Chrystus eucha-

7 Zmartwychwstały, jak zauważał już Ignacy Antiocheński, został ustanowiony Bogiem jako człowiek, również w człowieczeństwie stał się tym, kim już był (por. Rz 1,4) - Bernard Sesboüe, Joseph Wolinski, Bóg zbawienia. Tradycja, reguła i Symbole wiary. Ekonomia zbawienia. Rozwój dogmatów trynitarnych i chrystologicznych, red. nauk. pol. Tadeusz Dzidek, tłum. P. Rak (Kraków: Wydawnictwo M, 1999), 123. Akwinata zamiast formuły „człowiek stał się Bogiem” preferował: „stało się, że człowiek jest Bogiem” - Tomasz z Akwinu, „Sprostowanie błędów greckich”, tłum. J. Salij, część I, nr 21, w: Tomasz z Akwinu, Dzieła wybrane (Kęty: Wydawnictwo Antyk, 1999), 259-323, 284-285. Słowa Apostoła mówiące o ustanowieniu Chrystusa Panem ,znaczą właśnie to, co znaczą, czyli mówią o rzeczywistej przemianie - przebóstwieniu samego Jezusa, a nie tylko o ujawnieniu ludziom Jego niezmiennej, boskiej istoty” - Piotr Sikora, „Przebóstwienie człowieka, Chalcedon i chrystologia dwustopniowa", Polonia Sacra 12 (2003): 327-339, 338.

8 Sesboüé, Wolinski, Bóg zbawienia. Tradycja, reguła i Symbole wiary. Ekonomia zbawienia. Rozwój dogmatów trynitarnych i chrystologicznych, 303.

9 Międzynarodowa Komisja Teologiczna, Teologia, chrystologia, antropologia, I, E, 4. Według ojca Kościoła Wschodniego bracia Pierworodnego będą tam, gdzie teraz jest Głowa całego Ciała - Maksym Wyznawca, Antologia życia wewnętrznego. Dialog o życiu wewnętrznym. Księga Miłości. Księga Oświeconych. Wykład Modlitwy Pańskiej. List o miłości, tłum. Albert Warkotsch (Poznań: brw), 344.

10 KKK, 150.

$11 \mathrm{DV}, 11$. 
rystyczny, przyjmuje nas do swojego Ciała ${ }^{12}$. Jeśli poznajemy Boga, to jedynie dlatego, że On już nas poznał pierwszy i objawił się. Objawienie przyjmujemy wiarą, a ta nie jest panowaniem nad Bogiem, lecz właśnie poddaniem się Jemu. Pragniemy zrozumieć wiarę, ale okazuje się, że to nie my ją, lecz ona nas ogarnia - ta wiara raz dana świętym (Jud 3), czyli Kościołowi, który jako Ciało Chrystusa jest uprzedni względem wszystkich swoich członków oraz Kościołów partykularnych ${ }^{13}$.

W tym Kościele uprawiana teologia ,,chce nie tyle posiąść Boga, ile być przez Niego posiadaną" ${ }^{14}$. Dlatego nexus mysteriorum, sieć tajemnic wiary, nie może być rozumiana w ten sposób, jakby dało się w nią złapać Boga, owszem, to właśnie On pierwej obejmuje wierzących siecią tego, co objawił. Jeśli Bóg ma być wszystkim we wszystkich (por. 1 Kor 15,28), wszystko powinno zostać w tę sieć objawienia złowione. Dlatego Duch Święty prowadzący Kościół do całej prawdy (J 16,13) stopniowo wypełnia prześwit oczek sieci. „Reguła wiary”, czyli podstawowe prawdy objawione i wyznawane w symbolu wiary, to ,węzły” sieci. Można w nich widzieć fundamentalną konstrukcję, na bazie której sieć może być „uszczelniana”, tak żeby zagarnęła całą rzeczywistość.

Wśród stu pięćdziesięciu trzech ryb złowionych przez Piotra i pozostałych Apostołów (por. J 21,11) znalazły się również dwa ostatnie dogmaty maryjne, których nie dałoby się wyprowadzić z samego Pisma Świętego bez uwzględnienia zmysłu wiary (sensus fidei $^{15}$. Z kolei uroczyste ogłoszenie ,nowych” prawd wiary sprawia, że odtąd stają się one częścią tej całości, w zgodzie z którą należy pozostawać. W ten sposób powstaje sieć o gęstszych oczkach, albo raczej ukazuje się wierzącym już uprzednio istniejąca sieć. Należy bowiem pamiętać o uprzedniości całości nexus mysteriorum przed poszczególnymi prawdami wiary czy nawet ich sumą. Wszak Bóg objawiający siebie, a wtórnie wszystko sub ratione Dei, zarzuca całą sieć od razu.

12 Benedykt XVI, Adhortacja „,Sacramentum caritatis” (Rzym, 2007), 70: „Ma znaczenie w tym miejscu to, co św. Augustyn mówi w swych Wyznaniach o wieczystym Logosie, pokarmie duszy, gdy ukazując Jego paradoksalny charakter, wyobraża sobie, że w dialogu z Nim słyszy słowa: «Jam pokarm dorosłych, dorośnij, a będziesz mnie pożywał i nie wchłoniesz mnie w siebie, jak się wchłania cielesny pokarm, lecz ty się we mnie przemienisz»». W rzeczywistości to nie pokarm eucharystyczny przemienia się w nas, ale my w sposób tajemniczy jesteśmy w niego przemienieni. Chrystus karmi nas, jednocząc ze sobą: «On nas przyjmuje i przyciąga do siebie»”; Joseph Ratzinger, Eucharystia. Bóg blisko nas, tłum. Monika Rodkiewicz (Kraków: Wydawnictwo M, 2005), 87-88: Eucharystyczna obecność „nie jest czymś zamkniętym w sobie, lecz jest mocą, która sięga ku nam, chce nas przyjąć i wprowadzić w siebie (...) w przypadku zwykłego posiłku jest tak, że człowiek staje się po nim silniejszy. Przyjmuje pokarm, który staje się częścią jego własnej substancji. Pokarm przemienia się w człowieka i buduje jego cielesną egzystencję. Natomiast we wspólnocie z Chrystusem jest odwrotnie: On jest centrum, On jest istotą. Kiedy prawdziwie przyjmujemy Komunię św., oznacza to, że jesteśmy wyjęci z nas samych, wtopieni w Niego, stajemy się jednym z Nim i przez Niego oraz ze wspólnotą braci”.

13 Międzynarodowa Komisja Teologiczna, „Wybrane zagadnienia z eklezjologii”, tłum. Andrzej Michalik, 5.2, w: OWDT, 197-236; Kongregacja Nauki Wiary, „List do biskupów Kościoła katolickiego o niektórych aspektach Kościoła pojętego jako komunia «Communionis notio»", 9, w: Kongregacja Nauki Wiary, $W$ trosce o petnię wiary. Dokumenty Kongregacji Nauki Wiary 1966-1994, red. i tłum. Janusz Królikowski, Zygmunt Zimowski (Tarnów: Biblos, 2010), 470-483; Bernard Prusak, „Theological considerations - hermeneutical, ecclesiological, eschatological regarding «Memory and reconciliation: the church and the faults of the past», Horizons 32, 1 (2005): 136-151, 143.

14 Międzynarodowa Komisja Teologiczna, Teologia dzisiaj. Perspektywy, zasady i kryteria, thum. Krzysztof Stopa (Kraków: Wydawnictwo Księży Sercanów DEHON, 2012), 99 (dalej TD).

15 Międzynarodowa Komisja Teologiczna, ,Sensus fidei” w życiu Kościoła, tłum. Maria Moskal (Kraków: Wydawnictwo Księży Sercanów, 2015), 27, 34, 37-38, 40-42, 79 (dalej SF). 


\section{Hierarchia prawd - fundament całości}

Misterium Trójcy Świętej, centralna dla życia chrześcijańskiego, wiary oraz teologii tajemnica, stanowi źródło dla pozostałych tajemnic, które oświetla swoim światłem ${ }^{16}$. W nim właśnie pozostałe objawione prawdy wiary odnajdują swoją jedność. Odniesione do Trójjedynego, tworzą pewną strukturę, w której należy widzieć i jedno, i drugie zarazem: sieć wzajemnych powiązań (nexus mysteriorum), jak i porządek (ordo), według którego są one zorganizowane. Wypowiedzi kolejnych watykańskich soborów odpowiadają temu stanowi rzeczy. Pierwszy przyznawał rozumowi oświeconemu wiarą możliwość ,jakiegoś” zrozumienia tajemnic wiary właśnie dzięki istniejącym inteligibilnym „powiązaniom tajemnic między sobą (łac. mysteriorum ipsorum nexu inter se)"17. Z kolei drugi skierował uwagę teologów katolickich podejmujących dialog z braćmi odłączonymi na to, że w ramach tego połączenia misteriów istnieje hierarchiczne uporządkowanie prawd wiary (hierarchia veritatum): „Porównując doktryny, niech pamiętają o istnieniu porządku czy «hierarchii» prawd nauki katolickiej (łac. «hierarchiam» veritatum doctrinae catholicae), ponieważ różny jest ich związek z fundamentami wiary chrześcijańskiej” (łac. cum diversus sit earum nexus cum fundamento fidei christianae) ${ }^{18}$.

Co jednak ciekawe, ojcowie Vaticanum Secundum widzieli w uwzględnieniu tej jakby „hierarchii” prawd drogę odkrywania niezgłębionych bogactw Chrystusa (por. Ef 3,8), a powiązanie traktatów z misterium Chrystusa i historią zbawienia miało służyć odnowieniu teologii ${ }^{19}$. Nexus mysteriorum byłby swego rodzaju układem luster, w którym jeden $\mathrm{z}$ aspektów objawionej tajemnicy odbijałby się w drugim, a sam byłby z kolei przez niego pogłębiany; dopiero w konsekwencji uwzględnienia tych „odbić” bogactwo Chrystusa mogłoby się ukazać pełniej ${ }^{20}$. Od drugiej zaś strony patrząc, w misterium Chrystusa dają się odnaleźć wzajemne związki i spójność dogmatów ${ }^{21}$. Jeśli Chrystus - Słowo Wcielone - odbija się w lustrach objawionych tajemnic, to z kolei każda z nich zostaje

16 KKK, 234; TD, 61.

17 TD, 67; Sobór Watykański I, „Konstytucja dogmatyczna o wierze katolickiej «Dei Filius»”, w: Breviarium fidei. Wybór doktrynalnych wypowiedzi Kościoła, red. Ignacy Bokwa (Poznań: Księgarnia Świętego Wojciecha, 2007), 653: „Kiedy zaś rozum oświecony wiarą szuka starannie, nabożnie i trzeźwo, otrzymuje z daru Bożego jakieś zrozumienie - i to bardzo owocne - tajemnic, bądź dzięki analogii z rzeczami, które poznaje w sposób naturalny, bądź dzięki powiązaniom tajemnic między sobą i z celem ostatecznym człowieka”.

18 Sobór Watykański II, „Dekret o ekumenizmie «Unitatis redintegratio»”, 11 (dalej UR), w: SWKDD, $193-208$. Można mówić o obiektywnej oraz subiektywnej hierarchii prawd wiary - pierwsza wynika ze związku danej prawdy z fundamentami wiary chrześcijańskiej, druga wiąże się z egzystencjalnym znaczeniem prawdy wiary „Hierarchia prawd”, w: Herbert Vorgrimler, Nowy leksykon teologiczny, tłum. i oprac. Tadeusz Mieszkowski (Warszawa: Wydawnictwo Księży Werbistów, 2005), 116.

19 UR, 11; Sobór Watykański II, „Dekret o formacji kapłańskiej «Optatiam totus»”, 16, w: SWKDD, 288-301; Sobór Watykański II, „Konstytucja dogmatyczna o Kościele «Lumen gentium»”, 25, w: SWKDD, 104-166; Kongregacja Nauki Wiary, „Deklaracja o katolickiej doktrynie o Kościele przeciw niektórym współczesnym błędom «Mysterium Ecclesiae»”, 4, w: Kongregacja Nauki Wiary, W trosce o petnię wiary, 65-77; „Hierarchia prawd”, w: Leksykon pojęć teologicznych i kościelnych z indeksem angielsko-polskim, red. Gerald O’Collins, Edward Farrugia, tłum. Jan Ożóg, Barbara Żak (Kraków: Wydawnictwo WAM, 2002), 108.

20 Tę metaforę wykorzystał Hans Urs von Balthasar, który mówił o pojedynczych „lustrach” Ewangelii, w których odbija się osoba i rola Matki Bożej - Joseph Ratzinger (Benedykt XVI), Hans Urs von Balthasar, Maryja w tajemnicy Kościoła, tłum. Wiesław Szymona (Kraków: Wydawnictwo WAM, 2007), 88.

21 KKK, 90. 
pogłębiona przez Niego. „Znacie przecież łaskę Pana naszego, Jezusa Chrystusa, który będąc bogatym, dla was stał się ubogim, aby was ubóstwem swym ubogacić" (2 Kor 8,9).

Ojcowie soborowi wezwali chrześcijan do tego, by wyznawali wiarę w jednego Boga w Trójcy oraz we Wcielonego Syna Bożego, a zarazem Zbawiciela i Pana ludzi ${ }^{22}$. Ponieważ słowa te następują bezpośrednio po zasygnalizowaniu „hierarchii” prawd, wydają się wskazywać na to - zauważa Józef Majewski - że autorzy dokumentu właśnie doktrynę trynitologiczną oraz chrystologiczno-soteriologiczną uznają za fundament wiary chrześcijańskiej. Oznacza to, że w tak rozumianej „hierarchii” prawd wolno widzieć centrum, wokół którego cała struktura doktryny wiary zostaje zogniskowana ${ }^{23}$. W ten sposób szczyt hierarchii okazuje się fundamentem służącym całej strukturze, zgodnie z prawem Królestwa Bożego: kto chce stać się wielkim, ten służy. „Bo i Syn Człowieczy nie przyszedł, aby Mu służono, lecz żeby służyć i dać swoje życie jako okup za wielu" (Mk 10,44). Lampa Trójcy Świętej zaświeciła ludziom w Słowie stającym się człowiekiem, z kolei inkarnacja dokonała się „dla nas i dla naszego zbawienia”, dlatego w tajemnicy Chrystusa należy ujrzeć również tajemnicę odkupienia człowieka, a razem z nim również całej rzeczywistości stworzonej ${ }^{24}$.

\section{Chrystocentryzm, nie chrystomonizm}

Zdaniem Czesława Bartnika teologia jest dociekaniem tej Prawdy, którą jest sam Jezus Chrystus. Ten zaś odbija się we wszystkich aspektach, ujęciach, sformułowaniach doktryny katolickiej. Jest obecny cały w każdym dogmacie (totus in fragmento) i zarazem cały w doktrynie. W związku z tym, mimo że w całym systemie doktrynalnym zachodzi hierarchia veritatum, to każdy z dogmatów jest pewną całością chrześcijańską. Wszystkie dogmaty - każdy z osobna oraz ich wzajemne sploty (nexus dogmatum) - stają się zatem ikoną Jezusa Chrystusa ${ }^{25}$. Dopowiedzmy, że jeśli ikonę się pisze, można to robić w obrazie malowanym lub słownym. Oczywiście, prawdy wiary są jedynie i aż doktrynalnym aspektem Logosu, który wymaga połączenia z życiem Słowa w Jego Kościele. Jednak, jeśli nie wolno dzielić Chrystusa (por. 1 Kor 1,13), nie wolno też izolować czy tym bardziej marginalizować rzekomo drugorzędnych prawd wiary. Dopiero harmonia veritatum odzwierciedla w porządku doktryny całego Chrystusa, dzięki któremu z kolei jest możliwa hierarchia veritatum.

22 UR, 12; TD, 74.

23 Józef Majewski, „Wprowadzenie do teologii dogmatycznej”, w: Dogmatyka. Tom 1, red. Elżbieta Adamiak, Andrzej Czaja, Józef Majewski (Warszawa, 2005), 13-234, 166-167.

24 Jeden z ojców Vaticanum Secundum widział wszystkie prawdy objawienia w odniesieniu do dogmatu chrystologiczno-soteriologicznego (Chrystus sam w sobie i Chrystus dla nas). Konsekwentnie perspektywa soboru w Chalcedonie była dla niego kluczem interpretacyjnym całej doktryny: o Bogu, człowieku, Kościele, stworzonym świecie, historii i eschatologii. W każdej prawdzie wiary należy zachować charakterystyczną dwubiegunowość, analogicznie jak w Chrystusie jednoczą się dwie natury - Cipriano Vagaggini, Teologia. Pluralizm teologiczny, tłum. Jakub Partyka (Kraków: Homini, 2005), 154-155, 163, 174.

25 Czesław Stanisław Bartnik, Dogmatyka katolicka, t. I: Traktaty I-VI (Lublin: Wydawnictwo KUL, 2012), 9; Czesław Stanisław Bartnik, „Metodologia teologii dogmatycznej”, Studia nauk teologicznych 2 (2007): 165-173, 170; Henri de Lubac, Medytacje o Kościele, tłum. Izabela Białkowska-Cichoń (Kraków: Wydawnictwo WAM, 1997), 25 . 
Według Hansa Ursa von Balthasara wszystkie kwestie teologiczne o tyle zyskują swój sens, o ile zostają zintegrowane $\mathrm{w}$ całość oraz $\mathrm{z}$ całości tej wyprowadzone ${ }^{26}$. W każdym teologicznym dociekaniu należy uwzględnić konieczność zarazem integrowania prawd wiary w ścisłą całość (harmonia veritatum), jak i ich porządkowania według pewnego rankingu (hierarchia veritatum) ${ }^{27}$. Również, aby zrozumieć dogmat, należy wyjść z wewnętrznego powiązania wszystkich dogmatów dokonującego się według pewnego porządku. Ten zaś wynika z relacji każdego dogmatu do misterium Chrystusa, które jest chrystologicznym fundamentem wiary chrześcijańskiej. Stąd wolno, według Międzynarodowej Komisji Teologicznej, mówić o „chrystocentryzmie” jako kryterium interpretacji dogmatów ${ }^{28}$.

W związku z tym gremium teologów sugeruje tzw. zasadę reductio in Mysterium będącą wyrazem dynamizmu jednoczącego wypowiedzi teologiczne ${ }^{29}$. Zasadę tę, zdaniem szwajcarskiego członka Międzynarodowej Komisji Teologicznej, można rozumieć chrystologicznie $^{30}$. Z kolei pochodzący z Francji członek komisji wolał mówić o „koncentracji chrystologicznej”, która nie byłaby czystym „chrystocentryzmem” ani tym bardziej „,chrystomonizmem”31. Owszem, jak wszystko zostało stworzone w Chrystusie, przez i dla Niego (por. Kol 1,16), tak chrystologiczne centrum wydobywa z wydawałoby się peryferyjnych prawd właściwe im znaczenie. Walter Kasper, również członek komisji, komentując jedenasty numer Unitatis redintegratio, zwrócił uwagę, że byłoby błędem rozumienie ,hierarchii” prawd w sensie odróżniania tych ważnych od mniej ważnych; zresztą, wagę swoją zachowuje również to, co nie jest najważniejsze. W rozważaniu wiary nie chodzi o ilościowe wyliczanie prawd wiary, ale o jakościowe wnikanie w to, co zostało objawione. Treść wiary nie jest jedynie sumą poszczególnych twierdzeń, ale pewną całością, której struktura winna zachować określone proporcje składających się na nią elementów. Według tego członka Międzynarodowej Komisji Teologicznej to, że wszystkie dogmaty trzeba rozumieć chrystologicznie, nie może stawać się zasadą wyboru, lecz ma stanowić zasadę ich interpretacji. Wszystkie prawdy wiary, również te znajdujące się dalej od fundamentu, mają ułatwiać dostęp do jedynego Słowa, które w nich może zostać usłyszane ${ }^{32}$.

26 Hans Urs von Balthasar, Duch chrześcijański, tłum. Zofia Włodkowa (Poznań: W drodze, 2013), 13.

27 Bartnik, „Metodologia teologii dogmatycznej”, 167, 170.

28 Międzynarodowa Komisja Teologiczna, Interpretacja dogmatów, ID B, III, 3; C, I, 4. Komisja łączy chrystocentryzm z faktem, że Tajemnica Boga została objawiona w Chrystusie mocą Ducha Świętego - TD, 74.

29 TD, 74.

30 Balthasar, Duch chrześcijański, 13; Ignacy Bokwa, „Kształtowanie się problematyki chrystologiczno-eschatologicznej w twórczości Hansa Ursa von Balthasara (1905-1988)", Studia Theologica Varsaviensia 1 (1996): 178-179.

31 Henri de Lubac, Słowo Boga w historii człowieka, tłum. B. Czarnomska (Kraków: Wydawnictwo M, Wydawnictwo Znak, 1997), 36.

32 Walter Kasper, Rzeczywistość wiary, tłum. Jerzy Piesiewicz (Warszawa: PAX, 1979), 85-86. 


\section{Zasada interpretacji, nie marginalizacji}

Idea „hierarchii” prawd wiary, wyartykułowana przez ojców soboru zrazu w kontekście ekumenicznym oraz misyjnym, została, co zrozumiałe, wykorzystana przez teologów katolickich również $\mathrm{w}$ ich pracy systematycznego wyjaśniania i porządkowania nexus mysteriorum $^{33}$. Przy czym - a to już trudno usprawiedliwić - zasada hermeneutyczna stawała się nieraz instrumentem użytecznym do marginalizowania prawd rzekomo mniej ważnych. W ten sposób jednak zanegowano organiczną łączność całej doktryny, która, jeśli ma mieć uporządkowaną hierarchicznie strukturę, nie może przecież zostać zredukowana do tego, co centralne. Narzędzie selekcji, które uczyniono sobie ze skądinąd oczywistego stwierdzenia o ,hierarchii” prawd wiary, rozcięło sieć objawienia ${ }^{34}$. Nie spełnia ona już swojego zadania: ani Bogu nie pozwala się złowić w nią człowieka, ani w niej nie ukazuje się całe bogactwo Chrystusa.

Tego „ucho katolickie ścierpieć nie mogło"35, dlatego Kongregacja Nauki Wiary podtrzymała pogląd, że przyjęcie przez wiarę objawiającego się w Chrystusie Boga zakłada przylgnięcie do pełnego nauczania wiary katolickiej. Zgodnie z wypowiedzią soboru istnieje porządek i ,jakby hierarchia dogmatów Kościoła”, ale nie należy jej rozumieć w taki sposób, jakby nie wszystko, co objawione, należało przyjąć wiarą Boską. Owszem, hierarchia ukazuje, że niektóre dogmaty opierają się na innych, fundamentalnych, które je oświetlają ${ }^{36}$. Słowo, które stało się człowiekiem, zostało wypowiedziane wtórnie również w języku doktrynalnym. Izolowanie dogmatu z całości i oddzielenie go od życiodajnego centrum Chrystusowego - powoduje jego śmierć. Z kolei okaleczenie organicznej łączności całej doktryny powoduje, że nie może ujawnić swojej pełnej zbawczej mocy. Tak bowiem prawdy wiary zostały objawione dla zbawienia człowieka! Można w nich widzieć precyzyjny system ratowania życia wiecznego człowieka.

Wydaje się, że można by w nexus mysteriorum widzieć niemal jakiś żywy organizm, który potrzebuje współpracy każdego z elementów dla utrzymania się przy życiu; albo, jeśli pamiętać o soteriologicznym znaczeniu doktryny, wolno w niej widzieć najbardziej precyzyjny system dla ratowania życia wiecznego człowieka. Wydaje się, że w punkt

33 Zrozumiałe, że jeśli prawdy wiary tworzą sieć wzajemnych i charakteryzujących się pewnym porządkiem połączeń między sobą, teologia dogmatyczna winna służyć ukazaniu tej wewnętrznej jedności objawienia. Będzie zatem dogmatyka systematyzacją tego, co objawione, według pewnej hierarchizującej perspektywy oraz z uwzględnieniem powiązań idei przewodnich. „Hierarchia” prawd wiary nie oznacza w sposób konieczny, że na początku dogmatyki należałoby umieścić naukę o Bogu czy Chrystusie, zwłaszcza że dogmatyka będzie chciała się podjąć łączenia historiozbawczego wymiaru objawienia (Bóg objawia się jako Trójjedyny dopiero w wydarzeniu Chrystusa) z systematyzacją (od początku historii zbawienia Bóg jest przecież Trójcą). Gerhard Ludwig Müller, obecny przewodniczący Międzynarodowej Komisji Teologicznej, traktat o Trójcy Świętej usytuował w centrum kolejności traktatów właśnie ze względu na uwzględnienie historiozbawczego objawienia się Trójjedynego - Gerhard Ludwig Müller, Dogmatyka katolicka, tłum. Wiesław Szymona (Kraków: Wydawnictwo WAM, 2015), 77-78, 81.

34 „Hierarchia prawd”, w: Leksykon pojęć teologicznych i kościelnych z indeksem angielsko-polskim, 108: „zasada interpretowania (nie selekcjonowania!) prawd wiary oparta na tym, jak się one zbliżają do centralnej tajemnicy wiary, mianowicie do objawienia Trójcy Przenajświętszej, które nam przyniósł Chrystus i przez które zostaliśmy zbawieni w Duchu Świętym".

35 Leon Wielki, Mowy, tłum. Kazimierz Tomczak (Poznań-Warszawa-Lublin: Księgarnia Świętego Wojciecha, 1958), 118 (mowa nr 28).

36 Kongregacja Nauki Wiary, „Mysterium Ecclesiae”, 4; Sobór Watykański II, „Lumen gentium”, 25. 
trafił znany apologeta, który najsubtelniejsze doktrynalne rozróżnienia porównał „do precyzyjnych operacji chirurgicznych; separują nerw od nerwu, lecz ratują życie”. Należałoby przejąć się, zwłaszcza teologom, nad słowami konwertyty: „Nic prostszego, jak wyrównać całą okolicę przy pomocy dynamitu, jeśli jedynym naszym celem jest niesienie śmierci; lecz tak jak fizjolog ma do czynienia z żywymi tkankami, tak też teolog pracuje na żywych ideach. Jeśli je rozgranicza, musi to zrobić starannie i dokładnie"37.

\section{Sensus fidei a ordo veritatum}

Być może u źródła nieortodoksyjnego rozumienia „hierarchii” prawd wiary leży utrata sensus fidei. Właśnie zmysł wiary pozwala uchwycić całość (czy lepiej: dać się jej pochwycić) i w zgodzie z nią pojmować poszczególne tajemnice (a raczej: dać się im obejmować). Nie wystarczy teologowi poznawanie poszczególnych misteriów niejako „po kolei” - w ten sposób, nawet gdyby udało się zreflektować wszystkie prawdy wiary, i tak całość nexus mysteriorum nie zostałaby jeszcze uchwycona. Nie uwzględniono by ich wzajemnych zależności oraz tej racji jedności, która sprawia ich związek. Cały proces teologiczny winien zatem opierać się na dogłębnym przeżywaniu jedności objawienia oraz wiary, a dzięki namaszczeniu Ducha Świętego wierzący może liczyć na pewnego rodzaju nadprzyrodzony ,instynkt” w posługiwaniu się „lustrami” poszczególnych tajemnic oraz w uchwyceniu całości. Sensus fidei jest zdolnością „do intuicyjnego, doświadczeniowego i przedpojęciowego poznania w miłości prawdy objawionej, trwania w niej i pojmowania tego, w co Kościół wierzy i co głosi w określonym czasie i w określonej kulturze" 38 .

W nieskończoność pogłębiające się w lustrach prawd wiary „odbicia”, a zwłaszcza świadomość niezgłębionego bogactwa Chrystusa odzwierciedlającego się w poszczególnych prawdach i w ich całości, wymaga od teologa pokory, a teologię skierowuje ku apofatyzmowi, który zawsze winien towarzyszyć katafatycznemu wymiarowi scientia $D e i^{39}$. Ani wiara nie jest panowaniem nad Bogiem, owszem, jest posłuszeństwem Mu okazywanym (por. Rz 1,5; 16,26; 2 Kor 10,5-6), ani teologia nie może posiąść Boga, owszem, winna być przez Niego posiadana. Zatem należy uznać, że to nie tyle chrześcijanin ogarnia wiarę, ile właśnie pozwala na to, żeby ona objęła jego. Raz jeszcze trzeba oddać pierwszeństwo całości objawienia przed oglądem szczegółowych prawd wiary oraz ich wzajemnych związków ${ }^{40}$.

Teolog musi być ogarnięty przez nexus mysteriorum, jeśli ma nad poszczególnymi „węzłami” sieci rozważać. Nie wystarczy skoncentrować się na Chrystusie, żeby uprawiać chrystocentryczną refleksję. Dopiero całość odsyła do Tego, w którym kryją się wszelkie skarby mądrości i wiedzy (por. Kol 2,3). Z kolei jedynie ten, który w sieci misteriów

\footnotetext{
37 Gilbert Keith Chesterton, Dla sprawy, tłum. Jaga Rydzewska (Warszawa: Fronda, 2013), 123-124.

38 Majewski, „Wprowadzenie do teologii dogmatycznej”, 91.

39 TD, 96-97.

40 Paweł Borto, Teoria i praktyka uwzględniania ,sensus fidelium” przez Magisterium w czasach nowożytnych, w: Wiara - wiarygodność, red. Damian Wąsek (Kraków: Stowarzyszenie Teologów Fundamentalnych w Polsce, Uniwersytet Papieski Jana Pawła II w Krakowie, 2014), 115-141, 134.
} 
dostrzega Chrystusowe uporządkowanie, z właściwej perspektywy patrzy na całość ${ }^{41}$. Zmysł wiary, ten z Ducha Chrystusowego pochodzący duchowy „węch”, umożliwi mu odczuwanie woni Chrystusa (2 Kor 2,14) w całości i we wszystkich poszczególnych tajemnicach wiary, które okazują się nie tylko zgodne, ale i zrekapitulowane w Chrystusie. Zrozumiałe, że przylgnięcie do słownej ikony Chrystusa jest możliwe tylko pod warunkiem osobistej relacji z Osobą Słowa.

\section{Zakończenie}

Jeśli teologię wolno widzieć za francuskim filozofem jako misteryjnie ustrukturyzowaną pajęczynę, to z kolei na nexus mysteriorum trzeba by spoglądać jak na żywy organizm. Byłaby ona żywym Słowem, Chrystusem Wcielonym, tyle że obecnym w aspekcie doktrynalnym - treści objawienia nie wolno bowiem rozdzielać od Objawionego. Gdy tak pojmuje się depozyt wiary, cześć, z jaką należy przyjmować orzeczenia Kościoła, nabiera właściwej perspektywy. Jak hierarchiczny urząd w Kościele nie panuje nad Słowem Bożym, ale mu służy ${ }^{42}$, w ten sposób oddając pożytek całości Eklezji, tak z kolei hierarchia prawd wiary pozostaje w służbie całego mającego zbawcze znaczenie depositum fidei. A ten w całości oraz w każdej swojej poszczególnej tajemnicy ukazuje wierzącym Chrystusa, a w Jego świetle wszystkie prawdy otrzymują swoje znaczenie. „On jest obrazem Boga niewidzialnego - Pierworodnym wobec każdego stworzenia, bo w Nim zostało wszystko stworzone (...) Wszystko przez Niego i dla Niego zostało stworzone" (Kol 1,15-16).

\section{Bibliografia}

Atanazy z Aleksandrii. O wcieleniu Słowa. Tłum. Michał Wojciechowski. Warszawa: Akademia Teologii Katolickiej, 1998.

Balthasar, Hans Urs von. Duch chrześcijański. Tłum. Zofia Włodkowa. Poznań: W drodze, 2013.

Bartnik, Czesław Stanisław. „Metodologia teologii dogmatycznej”. Studia nauk teologicznych 2 (2007): 165-173.

Bartnik, Czesław Stanisław. Dogmatyka katolicka, t. I: Traktaty I-VI. Lublin: Wydawnictwo KUL, 2012.

Benedykt XVI. Adhortacja ,Sacramentum caritatis”. Rzym, 2007.

Bokwa, Ignacy. „Kształtowanie się problematyki chrystologiczno-eschatologicznej w twórczości Hansa Ursa von Balthasara (1905-1988)". Studia Theologica Varsaviensia 1 (1996): 178-179.

\footnotetext{
41 Majewski, „Wprowadzenie do teologii dogmatycznej”, 90: „Gdy kochamy Chrystusa, znamy Prawdę, całą Prawdę, bo kochamy całą osobę Chrystusa, chociaż jednocześnie nie znamy tej Prawdy pod każdym względem czy w każdym wymiarze".

42 DV, 10.
} 
Borto, Paweł. „Teoria i praktyka uwzględniania «sensus fidelium» przez Magisterium w czasach nowożytnych". W: Wiara - wiarygodność, red. Damian Wąsek, 115-141. Kraków: Stowarzyszenie Teologów Fundamentalnych w Polsce, Uniwersytet Papieski Jana Pawła II w Krakowie, 2014.

Chesterton, Gilbert Keith. Dla sprawy. Tłum. Jaga Rydzewska. Warszawa: Fronda, 2013.

Dulles, Avery Robert. „From Ratzinger to Benedict”. First Things 160 (2006): 24-29.

„Hierarchia prawd”. W: Herbert Vorgrimler. Nowy leksykon teologiczny. Tłum. i oprac. Tadeusz Mieszkowski, 116. Warszawa: Wydawnictwo Księży Werbistów, 2005.

„Hierarchia prawd”. W: Leksykon pojęć teologicznych i kościelnych z indeksem angielsko-polskim, red. Gerald O’Collins, Edward Farrugia. Tłum. Jan Ożóg, Barbara Żak, 108. Kraków: Wydawnictwo WAM, 2002.

Jelonek, Tomasz. Biblia w nauczaniu Kościoła. Kraków: Wydawnictwo WAM, 2011.

Kasper, Walter. Rzeczywistość wiary. Tłum. Jerzy Piesiewicz. Warszawa: PAX, 1979.

Katechizm Kościoła katolickiego. Poznań: Pallottinum, 2002.

Kongregacja Nauki Wiary. „Deklaracja o katolickiej doktrynie o Kościele przeciw niektórym współczesnym błędom «Mysterium Ecclesiae»”. W: Kongregacja Nauki Wiary, W trosce o petnię wiary. Dokumenty Kongregacji Nauki Wiary 1966-1994, red. i tłum. Janusz Królikowski, Zygmunt Zimowski, 65-77. Tarnów: Biblos, 2010.

Kongregacja Nauki Wiary. „List do biskupów Kościoła katolickiego o niektórych aspektach Kościoła pojętego jako komunia «Communionis notio»”. W: Kongregacja Nauki Wiary, W trosce o petnię wiary. Dokumenty Kongregacji Nauki Wiary 1966-1994, red. i tłum. Janusz Królikowski, Zygmunt Zimowski, 470-483. Tarnów: Biblos, 2010.

Leon Wielki. Mowy. Tłum. Kazimierz Tomczak. Poznań-Warszawa-Lublin: Księgarnia Świętego Wojciecha, 1958.

Lubac de, Henri. Medytacje o Kościele. Tłum. Izabela Białkowska-Cichoń. Kraków: Wydawnictwo WAM, 1997.

Lubac de, Henri. Słowo Boga w historii człowieka. Tłum. B. Czarnomska. Kraków: Wydawnictwo M, Wydawnictwo Znak, 1997.

Majewski, Józef. „Wprowadzenie do teologii dogmatycznej”. W: Dogmatyka. Tom 1, red. Elżbieta Adamiak, Andrzej Czaja, Józef Majewski, 13-234. Warszawa, 2006.

Maksym Wyznawca. Antologia życia wewnętrznego. Dialog o życiu wewnętrznym. Księga Miłości. Księga Oświeconych. Wykład Modlitwy Pańskiej. List o miłości. Tłum. Albert Warkotsch. Poznań: brw.

Międzynarodowa Komisja Teologiczna. „Interpretacja dogmatów (1988)”, tłum. J. Królikowski. W: Od wiary do teologii. Dokumenty Międzynarodowej Komisji Teologicznej 1969-1996, red. Janusz Królikowski, 273-302. Kraków: Wydawnictwo Księży Sercanów SCJ, 2000.

Międzynarodowa Komisja Teologiczna. „Sensus fidei” w życiu Kościoła. Tłum. Maria Moskal. Kraków: Wydawnictwo Księży Sercanów, 2015.

Międzynarodowa Komisja Teologiczna. Teologia dzisiaj. Perspektywy, zasady i kryteria. Tłum. Krzysztof Stopa. Kraków: Wydawnictwo Księży Sercanów DEHON, 2012. 
Międzynarodowa Komisja Teologiczna. „Teologia, chrystologia, antropologia”, tłum. J. Bielecki. W: Od wiary do teologii. Dokumenty Międzynarodowej Komisji Teologicznej 1969-1996, red. Janusz Królikowski, 133-150. Kraków: Wydawnictwo Księży Sercanów SCJ, 2000.

Międzynarodowa Komisja Teologiczna. „Wybrane zagadnienia z eklezjologii”. W: Od wiary do teologii. Dokumenty Międzynarodowej Komisji Teologicznej 1969-1996, red. Janusz Królikowski. Tłum. Andrzej Michalik. Kraków: Wydawnictwo Księży Sercanów SCJ, 2000, 197-236.

Müller, Gerhard Ludwig. Dogmatyka katolicka. Tłum. Wiesław Szymona. Kraków: Wydawnictwo WAM, 2015.

Prusak, Bernard. „Theological considerations - hermeneutical, ecclesiological, eschatological regarding «Memory and reconciliation: the church and the faults of the past»»" Horizons 32, 1 (2005): 136-151.

Ratzinger, Joseph (Benedykt XVI), Hans Urs von Balthasar. Maryja w tajemnicy Kościoła. Tłum. Wiesław Szymona. Kraków: Wydawnictwo WAM, 2007.

Ratzinger, Joseph. Eucharystia. Bóg blisko nas. Tłum. Monika Rodkiewicz. Kraków: Wydawnictwo M, 2005.

Ratzinger, Joseph. Moje życie, oprac. wersji pol. Witold Wiśniowski. Częstochowa: Edycja Świętego Pawła, 2005.

Ratzinger, Joseph. Patrzeć na przebitego. Szkice o chrystologii duchowej. Tłum. Jarosław Merecki. Kraków: Salwator, 2008.

Schönborn, Christoph. Bóg zesłał Syna Swego. Chrystologia, współpr. Konrad Michael, Weber Hubert Philips. Tłum. Lucjan Balter. Poznań: Pallottinum, 2002.

Sesboüé, Bernard. Poza Kościołem nie ma zbawienia. Historia formuly i problemy interpretacyjne. Tłum. Agnieszka Kuryś. Poznań: W drodze, 2007.

Sesboüe, Bernard, Joseph Wolinski. Bóg zbawienia. Tradycja, reguła i Symbole wiary. Ekonomia zbawienia. Rozwój dogmatów trynitarnych i chrystologicznych, red. nauk. pol. Tadeusz Dzidek. Tłum. P. Rak. Kraków: Wydawnictwo M, 1999.

Sikora, Piotr. „Przebóstwienie człowieka, Chalcedon i chrystologia dwustopniowa”. Polonia Sacra 12 (2003): 327-339.

Sobór Watykański I. „Konstytucja dogmatyczna o wierze katolickiej «Dei Filius»”. W: Breviarium fidei. Wybór doktrynalnych wypowiedzi Kościoła, red. Ignacy Bokwa. Poznań: Księgarnia Świętego Wojciecha, 2007.

Sobór Watykański II. „Dekret o ekumenizmie «Unitatis redintegratio»”. W: Sobór Watykański II. Konstytucje, dekrety, deklaracje. Tekst polski. Nowe ttumaczenie. Poznań: Pallottinum, 2002, 193-208.

Sobór Watykański II. „Dekret o formacji kapłańskiej «Optatiam totus»”. W: Sobór Watykański II. Konstytucje, dekrety, deklaracje. Tekst polski. Nowe ttumaczenie. Poznań: Pallottinum, 2002, 288-301.

Sobór Watykański II. „Konstytucja dogmatyczna o Kościele «Lumen gentium»”. W: Sobór Watykański II. Konstytucje, dekrety, deklaracje. Tekst polski. Nowe thumaczenie. Poznań: Pallottinum, 2002, 104-166. 
Sobór Watykański II. „Konstytucja dogmatyczna o Objawieniu Bożym «Dei verbum»”. W: Sobór Watykański II. Konstytucje, dekrety, deklaracje. Tekst polski. Nowe tłumaczenie. Poznań: Pallotinum, 2002, 350-363.

Tomasz z Akwinu. „Sprostowanie błędów greckich”, tłum. Jacek Salij. W: Tomasz z Akwinu. Dzieła wybrane. Kęty: Wydawnictwo Antyk, 1999: 259-323.

Vagaggini, Cipriano. Teologia. Pluralizm teologiczny. Tłum. Jakub Partyka. Kraków: Homini, 2005.

Zatwardnicki, Sławomir. „Relacja Objawienia do Pisma Świętego według Josepha Ratzingera (Benedykta XVI)". Teologia w Polsce 8, 1 (2014): 99-118.

\section{Streszczenie}

Istnieje związek objawienia się Boga z objawieniem prawd wiary. Pozostają one ze sobą wzajemnie powiązane (nexus mysteriorum) oraz uporządkowane wokół centrum wiary chrześcijańskiej (hierarchia veritatum). W artykule ukazano, w jaki sposób „hierarchia” prawd wiary winna przyczynić się do lepszego rozumienia wszystkich misteriów. Uwzględnienie tej hierarchii nie może prowadzić do marginalizowania pozostałych objawionych prawd wiary. Zmysł wiary (sensus fidei) pomaga w uwzględnieniu zarówno całości sieci misteriów, jak i poszczególnych tajemnic wiary oraz ich relacji z Chrystusowym ośrodkiem.

Słowa kluczowe: objawienie, nexus mysteriorum, hierarchia prawd, hierarchia veritatum, harmonia veritatum, Chrystus, chrystocentryzm, hermeneutyka, zmysł wiary, sensus fidei

\section{Abstract}

\section{CHRIST IN NEXUS MYSTERIORUM}

There is a connection between God's self-revelation and the revelation of the truths of faith. They remain mutually related (nexus mysteriorum) and arranged around the centre of the Christian faith (hierarchia veritatum). The article shows how the "hierarchy" of the truths of faith should contribute to a better understanding of all mysteries. While taking into account this hierarchy one must not marginalize other revealed truths of faith. The sense of faith (sensus fidei) helps to consider not only a net of mysteries as a whole but also particular mysteries of faith within it, as well as their correlation with Christ who is in the centre.

Keywords: Revelation, nexus mysteriorum, hierarchy of truths, hierarchia veritatum, harmonia veritatum, Christ, christocentrism, hermeneutics, instinct of faith, sensus fidei 